\title{
KORELASI TIMBAL DALAM DARAH DAN TINGKAT KECERDASAN (MAJEMUK) SISWA SEKOLAH DASAR DI SEKITAR PELEBURAN AKI BEKAS DI KABUPATEN TANGERANG DAN KABUPATEN LAMONGAN
}

\author{
CORRELATION BLOOD LEAD LEVELS AND INTELIGENCE \\ LEVELS AMONG ELEMENTARY SCHOOL STUDENTS LIVING AT \\ SURROUNDING USED BATTERY SMELTER IN THE REGENCY OF \\ TANGERANG AND LAMONGAN
}

\author{
Budiyono ${ }^{1}$, Budi Haryanto' ${ }^{1}$ Esrom Hamonangan², dan Bambang Hindratmo ${ }^{2}$
}

(Diterima tanggal 02-02-2016; Disetujui tanggal 06-03-2016)

\begin{abstract}
ABSTRAK
Pajanan timbal di dunia diperkirakan sebesar $0,6 \%$ penyebab penyakit global dengan proporsi terbanyak di negara-negara berkembang. Industri peleburan aki bekas, saat ini, menjadi perhatian para ahli kesehatan dan lingkungan karena potensinya sebagai sumber pencemar timbal. Racun timbal dalam tubuh akan merusak sistem saraf dan mengakibatkan penurunan Intelegence Quotient (IQ), terutama pada anak-anak karena masih diusia tumbuh kembang otak. Kadar timbal dalam darah merupakan indikator yang paling baik untuk menunjukkan current exposure. Penelitian ini bertujuan mengetahui hubungan kadar timbal dalam darah terhadap tingkat kecerdasan (majemuk) siswa sekolah dasar menggunakan rancangan studi cross sectional. Kecerdasan majemuk yang diukur adalah kecerdasan verbal dan kecerdasan logis-matematis. Sebanyak 60 siswa MI Baitussaa'adah di Kabupaten Tangerang dan 69 siswa SDN Bulutengger di Kabupaten Lamongan diukur kadar timbal darah dan laporan prestasi belajarnya. Ditemukan kadar timbal dalam darah anak di Kabupaten Tangerang dengan rerata 39,18 $\mu \mathrm{g} / \mathrm{dl}(100 \%$ melebihi batas normal CDC 1997) dan rerata 11,76 $\mu \mathrm{g} / \mathrm{dl}$ (59,4\% melebihi batas normal) di Kabupaten Lamongan. Kadar timbal dalam darah berhubungan signifikan dengan tingkat kecerdasan majemuk (nilai $\mathrm{p}<0,05$ ) dan anak-anak yang kadar timbal darahnya tinggi berisiko mempunyai tingkat kecerdasan majemuk rendah sebesar hampir 3,5 kali dibandingkan dengan mereka yang berkadar timbal darah rendah (Odds Ratio=3,447). Semakin dekat jarak rumah terhadap sumber pencemar timbal, semakin rendah pendidikan orang tua, dan seringnya tidak masuk sekolah dengan alasan sakit juga ditemukan berisiko terhadap rendahnya tingkat kecerdasan majemuk. Walaupun begitu, hanya rendahnya pendidikan orang tua yang ikut mempengaruhi hubungan kadar timbal dalam darah dengan tingkat kecerdasan (majemuk) anak-anak dalam analisis lanjut. Penelitian ini menyimpulkan bahwa pajanan timbal karena peleburan aki bekas sudah membahayakan. Disarankan agar industri yang menggunakan timbal harus ditutup di wilayah tersebut atau dipindahkan menjauh dari pemukiman masyarakat.
\end{abstract}

Kata kunci: peleburan aki bekas, timbal dalam darah anak, kecerdasan majemuk

\begin{abstract}
Lead exposures in the world were estimated at $0.6 \%$ of the global disease burden with the highest is in developing countries. The industry of battery recycling now becomes a big concern of lead exposure sources. Lead toxicity in human body may affects nervous system and decrease IQ points especially among children whose on the ages of physical and brain development. Blood lead levels are wellknown as the best indicator for current exposure. The objective of this study is to determine the relationship between blood lead levels and multiple intelligence levels among elementary school children by utilizing a cross sectional design study. Children's intelligence levels were analized by scoring of reported verbal and logical-mathematical intelligence. Sixty students of MI Baitussaa'adah in Tangerang and 69 students of SDN Bulutengger in Lamongan were participated the study. It was found that the average of children's blood lead levels (BLLs) in Tangerang is 39,18 $\mu \mathrm{g} / \mathrm{dl}$ (100\% elevated the CDC 1997 guideline) and $11,76 \mu \mathrm{g} / \mathrm{dl}(59,4 \%$ elevated the guideline) in Lamongan. The children's blood lead levels found
\end{abstract}

${ }^{1}$ Departemen Kesehatan Lingkungan Fakultas Kesehatan Masyarakat Universitas Indonesia

${ }^{2}$ Pusat Penelitian dan Pengembangan Kualitas dan Laboratorium Lingkungan, Kementerian Lingkungan Hidup dan Kehutanan RI 
significantly associated with multiple intelligences level ( $p$ value $<0.05$ ) with the risk of children with high BLLs is about 3.5 lower among those who have higher BLLs (OR =3.447). Living near the source of lead exposure, low level of parent education, and more frequent absence in the class because of ill were also associated with the level of children intelegence. However, only low level of parent education factor that involved in the further analysis of the association between children's BLLs and intelligence. This study suggests that the level of lead exposure from battery recycling process is already danger to people living in surrounding area. Therefore, the industry involving lead substances should be stopped or moved far away from the community.

Keywords: used lead battery recycling, children blood lead levels, multiple intelligences

\section{PENDAHULUAN}

Penggunaan timbal di dunia diperkirakan lebih dari $3 / 4$ berasal dari pabrik aki kendaraan bermotor [1,2]. Emisi timbal dari kegiatan peleburan timbal di negara berkembang terus menerus menjadi perhatian. Peleburan aki bekas umumnya menggunakan teknologi yang sederhana dan kurang memperhatikan aspek terkait pengendalian pencemaran. Data menunjukkan hampir 97\% aki di dunia mengalami daur ulang dan kebanyakan dilakukan secara informal di beberapa negara berpenghasilan rendah $[3,4]$. Blacksmith Institute menyebutkan bahwa saat ini terdapat sekitar 300.000 ton lebih aki bekas. Estimasi kapasitas peleburan aki bekas legal hanya 100.000 ton dan secara ilegal adalah 200.000 ton [5]. Pada tahun 2012, kegiatan daur ulang aki bekas di Jabodetabek teridentifikasi sebanyak 71 lokasi [6].

Peleburan aki bekas menghasilkan debu timbal yang berbahaya untuk kesehatan bila terpajan melampaui nilai ambang batas dalam waktu yang lama [7]. CDC dan EPA menentukan kadar timbal dalam darah $\geq 10$ $\mu \mathrm{g} / \mathrm{dl}$ sebagai nilai ambang batas [8]. Timbal dapat mengganggu perkembangan sistem saraf sehingga mengakibatkan penurunan IQ $[8,9]$. Anak-anak merupakan populasi rentan dikarenakan beberapa alasan seperti masih dalam tahap perkembangan otak; tingginya frekuensi makan, minum dan bernafas; hidup dalam satu lingkungan; memasukkan segala macam benda ke dalam mulut; dan dapat Pabrik peleburan aki bekas legal telah beroperasi di Kecamatan Curug, Kabupaten Tangerang sejak tahun 1987. Pencemaran udara akibat timbal juga terjadi di Lamongan. Lokasi peleburan aki bekas ini berada di pertengahan sawah dan terdapat sekitar 18 cerobong asap. Peningkatan konsentrasi timbal di udara dapat meningkatkan konsentrasi timbal dalam darah sehingga dapat mengganggu perkembangan kecerdasan (majemuk) pada anak-anak.

\section{METODOLOGI}

Penelitian ini menggunakan desain crosssectional dengan tujuan melihat besaran masalah kadar timbal dalam darah akibat asap peleburan aki bekas terhadap tingkat kecerdasan (majemuk) anak-anak yang belajar di sekolah berdekatan dengan lokasi peleburan aki bekas. Sampel darah perifer diambil dari ujung jari dan dianalisis dengan LeadCareII. Kadar timbal dalam darah merupakan indikator yang paling baik untuk menunjukkan current exposure dan lebih sering digunakan dibandingkan timbal pada gigi dan tulang. Pengambilan sampel dilakukan pada dua sekolah di lokasi yang berbeda yaitu 60 siswa MI Baitussaa'adah di Kabupaten Tangerang dan 69 siswa SDN 
Bulutengger di Kabupaten Lamongan. Anak SD terpilih karena masih dalam masa perkembangan kecerdasan (majemuk) seperti keterampilan dasar membaca, menulis dan matematika. Oleh karena itu, kecerdasan majemuk yang terdiri dari kecerdasan verbal dan kecerdasan logis-matematis dijadikan sebagai outcome. Tingkat kecerdasan (majemuk) diukur berdasarkan nilai tiga mata pelajaran yaitu bahasa Indonesia, bahasa Inggris dan matematika dengan pendekatan statistik analisis faktor. Kecerdasan (majemuk) tidak hanya dipengaruhi oleh timbal tetapi juga dipengaruhi oleh berbagai faktor. Faktor lain yang diteliti yaitu jenis kelamin, wilayah tinggal, pendidikan orang tua dan kesakitan. Analisis data menggunakan uji kai kuadrat dan uji regresi logistik ganda.

\section{HASIL DAN PEMBAHASAN}

\section{Distribusi Kadar Timbal Darah}

Hasil pengukuran menunjukkan 78,3\% (101 responden) memiliki kadar timbal darah $\geq 10$ $\mu \mathrm{g} / \mathrm{dl}$ dengan rata-rata $24,5 \mu \mathrm{g} / \mathrm{dl}$. Kadar timbal darah terendah adalah $5 \mu \mathrm{g} / \mathrm{dl}$ dan tertinggi $\geq 65,1 \mu \mathrm{g} / \mathrm{dl}$. Rata-rata kadar timbal dalam darah anak di Kabupaten Tangerang adalah $39,18 \mu \mathrm{g} / \mathrm{dl}$ dimana 100\% melebihi batas normal (CDC 1997) sedangkan Kabupaten Lamongan adalah 11,76 $\mu \mathrm{g} / \mathrm{dl}$ dimana 59,4\% melebihi batas normal

\section{Distribusi Tingkat Kecerdasan Majemuk}

Analisis univariat didapatkan rata-rata nilai bahasa Indonesia, bahasa Inggris dan matematika adalah $80 ; 73,8$; dan 76,1 . Rata-rata prestasi belajar pada ketiga mata pelajaran di Kabupaten Tangerang lebih rendah dibandingkan Kabupaten Lamongan. Ketiga nilai mata pelajaran disatukan dan dijadikan variabel kategorik dengan pendekatan statistik analisis faktor yaitu tingkat kecerdasan (majemuk) rendah sebanyak 61 (47,3\%) dan tinggi sebanyak 68 (52,7\%).

\section{Hubungan antara Kadar Timbal dalam Darah dan Variabel Lainnya dengan Tingkat Kecerdasan (majemuk)}

Kadar timbal dalam darah berhubungan signifikan $(\mathrm{p}=0,008)$ dengan tingkat kecerdasan (majemuk) dengan nilai $\mathrm{OR}=3,447$ yang

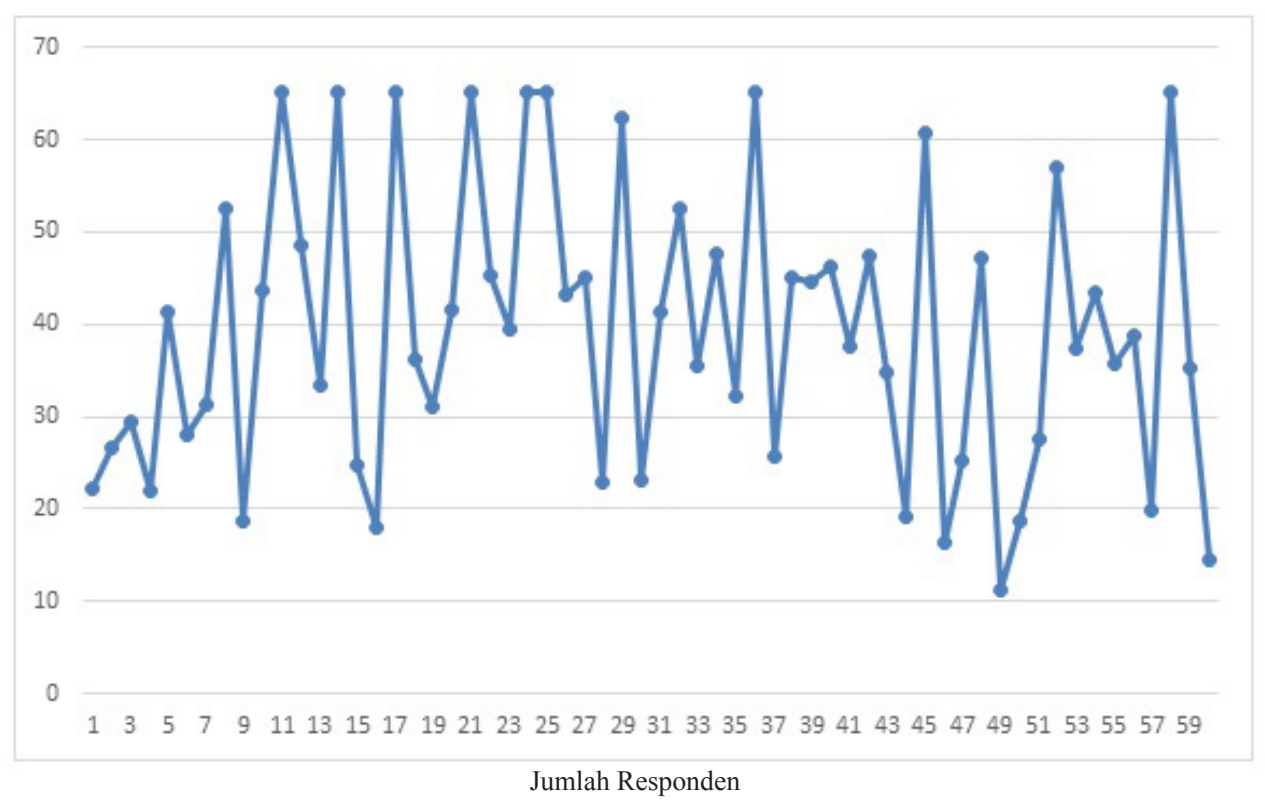

Gambar 1. Pengukuran kadar timbal darah di Kabupaten Tangerang 


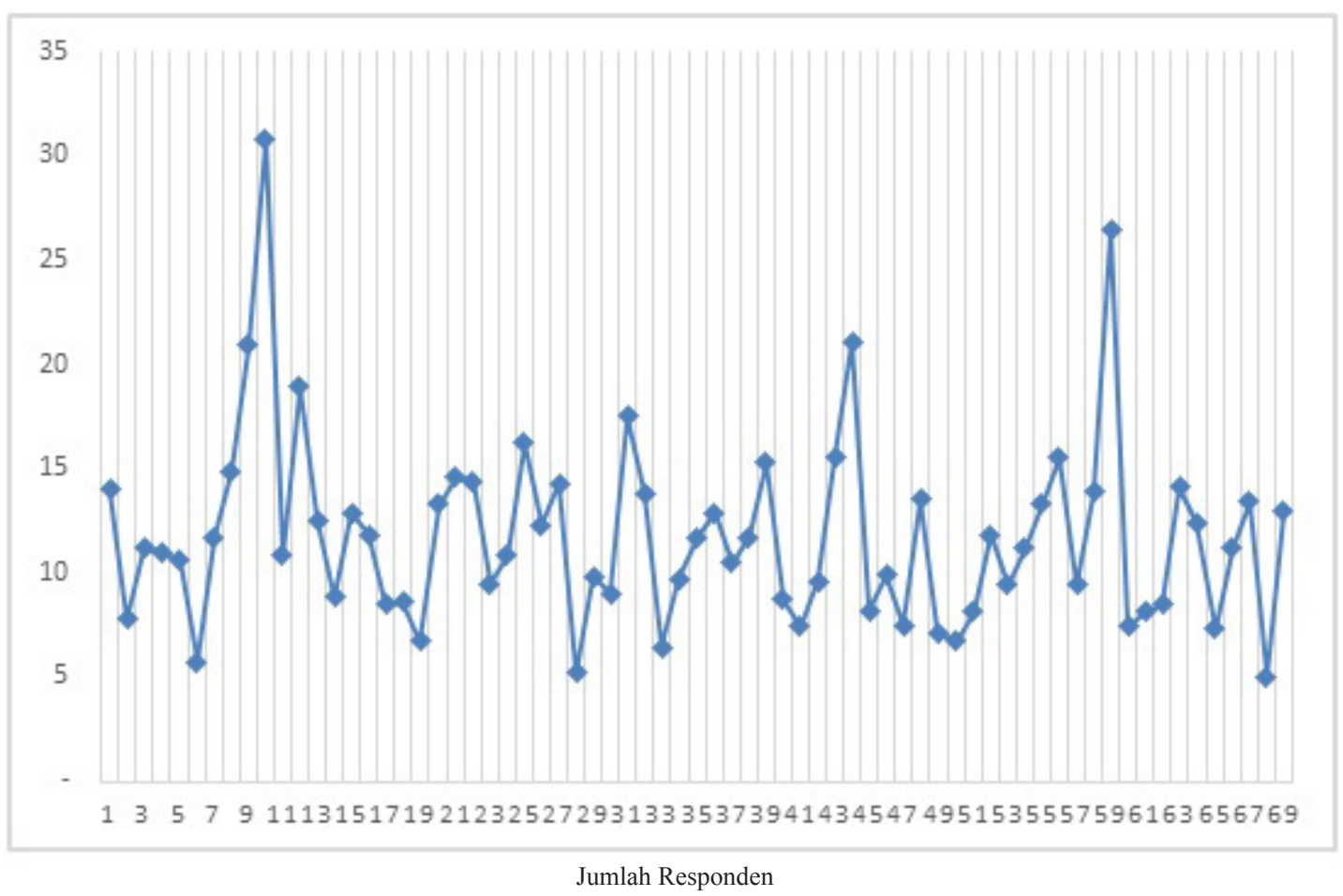

Gambar 2. Pengukuran kadar timbal darah di Kabupaten Lamongan

artinya siswa yang memiliki kadar timbal darah tinggi mempunyai peluang 3,4 kali untuk memiliki tingkat kecerdasan (majemuk) rendah. Dalam sistem saraf pusat, timbal menyebabkan kerusakan asimtomatik fungsi neurobehavioural pada

Penurunan ini dapat menyebabkan impaired cellular energetics sehingga menyebabkan beberapa dampak lanjutan pada neuron, axon, dan sel schwann; merusak myelination, dan sistem saraf; serta merusak pertumbuhan sistem saraf [10]. Penelitian Landrigan dkk (1979) menunjukkan bahwa anak-anak tanpa gejala klinis namun dengan peningkatan kadar timbal dalam darah mengalami defisit 4 sampai 5 poin skor IQ verbal. Penelitian Bellinger (1991) menunjukkan implikasi yang kuat bahwa kadar timbal dalam darah antara 10-25 $\mu \mathrm{g} / \mathrm{dl}$ telah cukup menyebabkan kerusakan otak [4]. Variabel lain yang berhubungan signifikan yaitu wilayah tinggal, pendidikan orang tua, dan kesakitan (Tabel

Wilayah tinggal berkaitan dengan lingkungan sekitar responden, ada tidaknya pajanan pencemaran timbal dan perbedaan sistem pengajaran di sekolah. Teori mengatakan apabila di lingkungan masih ada sumber pajanan timbal, maka timbal yang terabsorpsi dan terdeposit dalam tubuh semakin lama akan semakin banyak. Hal ini disebabkan timbal bersifat akumulatif dalam tubuh manusia pada pajanan yang berlangsung terus-menerus [10]. Tingkat pendidikan pengasuh utama merupakan salah satu pembaur dalam penelitian timbal dalam darah dan kemampuan kognitif [11]. Hal ini dapat dijelaskan bahwa semakin tinggi pendidikan orang tua, maka mereka akan memperhatikan pendidikan anak-anaknya dan memiliki keluangan waktu untuk mendidik. Orang tua yang lebih berpendidikan akan cenderung mencari tahu informasi untuk melindungi kesehatan anak-anaknya. Banyak penyakit endemik 
Tabel 1. Hubungan antara kadar timbal dalam darah dan variabel lainnya dengan tingkat kecerdasan (majemuk)

\begin{tabular}{|c|c|c|c|c|}
\hline \multirow{2}{*}{ Variabel } & \multicolumn{2}{|c|}{ Kecerdasan Majemuk } & \multirow{2}{*}{$\begin{array}{c}\text { OR } \\
(95 \% \mathrm{Cl})\end{array}$} & \multirow{2}{*}{ Nilai $\mathrm{F}$} \\
\hline & Rendah & Tinggi & & \\
\hline \multicolumn{5}{|c|}{ Kadar timbal dalam darah } \\
\hline Tinggi & $54(53,5 \%)$ & $47(46,5 \%)$ & \multirow{2}{*}{$\begin{array}{l}3,447 \\
(1,346-8,828)\end{array}$} & \multirow{2}{*}{0,008} \\
\hline Rendah & $7(25,0 \%)$ & $21(75,0 \%)$ & & \\
\hline \multicolumn{5}{|l|}{ Jenis kelamin } \\
\hline Laki-laki & $33(49,3 \%)$ & $34(50,7 \%)$ & \multirow{2}{*}{$\begin{array}{l}1,179 \\
(0,590-2,356)\end{array}$} & \multirow{2}{*}{0,642} \\
\hline Perempuan & $28(45,2 \%)$ & $34(54,8 \%)$ & & \\
\hline \multicolumn{5}{|l|}{ Wilayah tinggal } \\
\hline Tangerang & $41(68,3 \%)$ & $19(31,7 \%)$ & \multirow{2}{*}{$\begin{array}{l}5,287 \\
(2,491-11,221)\end{array}$} & \multirow{2}{*}{0,001} \\
\hline Lamongan & $20(29,0 \%)$ & $49(71,0 \%)$ & & \\
\hline \multicolumn{5}{|c|}{ Pendidikan orang tua } \\
\hline$\leq 9$ Tahun & $38(61,3 \%)$ & $24(38,7 \%)$ & \multirow{2}{*}{$\begin{array}{l}3,029 \\
(1,477-6,210)\end{array}$} & \multirow{2}{*}{0,002} \\
\hline$>9$ Tahun & $23(34,3 \%)$ & $44(65,7 \%)$ & & \\
\hline \multicolumn{5}{|l|}{ Kesakitan } \\
\hline Sakit & $41(60,3 \%)$ & $27(39,7 \%)$ & \multirow{2}{*}{$\begin{array}{l}3,113 \\
(1,512-6,410)\end{array}$} & \multirow{2}{*}{0,002} \\
\hline Tidak Sakit & $20(32,8 \%)$ & $41(67,2 \%)$ & & \\
\hline
\end{tabular}

Tabel 2. Permodelan terakhir multivariat

\begin{tabular}{lccc}
\hline Variabel & B & Nilai P & OR 95\%Cl \\
\hline Timbal dalam darah & 1,195 & 0,016 & $3,303(1,254-8,700)$ \\
Pendidikan orang tua & 1,078 & 0,004 & $2,938(1,407-6,136)$ \\
& & & \\
\hline
\end{tabular}

umum (termasuk malaria, schistosomiasis, dan demam berdarah) dapat mempengaruhi penyerapan timbal. Kadar timbal darah dan asupan makanan dari sejumlah zat gizi mikro seperti besi, seng, kalsium, vitamin $\mathrm{C}$ dan D berhubungan signifikan. Anak-anak yang kekurangan kalsium dapat menyerap lebih banyak timbal dibandingkan anak yang cukup kalsium [12]. Hal ini dikarenakan timbal menggantikan kation polyvalent (bagian dari kation divalent seperti kalsium/ $\mathrm{Ca}^{2+}$ dan zink/ $\mathrm{Zn}^{2+}$ ) pada proses molekuler tubuh. Timbal dapat mengikat protein dengan afinitas yang lebih besar dibandingkan ion kalsium dan ion zink [4]. Rekomendasi kesehatan masyarakat dewasa ini menyarankan pentingnya peningkatan asupan kalsium yang dapat memberikan perlindungan terhadap pajanan timbal [13].

\section{Analisis Multivariat}

Variabel independen yang memenuhi kriteria kandidat model multivariat (nilai $\mathrm{p} \leq 0,25$ ) adalah timbal dalam darah, wilayah, pendidikan orang tua dan kesakitan (Tabel 1). Berdasarkan uji analisis multivariat dengan regresi logistik 
ganda, variabel yang berpengaruh adalah pendidikan orang tua dengan nilai $\mathrm{OR}=$ 3,303 artinya siswa berkadar timbal darah tinggi berpeluang 3,3 untuk memiliki tingkat kecerdasan (majemuk) rendah dibandingkan siswa berkadar timbal darah rendah dengan setelah dikontrol variabel pendidikan orang tua (Tabel 2).

\section{SIMPULAN}

Dari berbagai hasil analisis data dan pembahasan dari temuan-temuan dalam penelitian, maka dapat dirangkum kesimpulan sebagai berikut:

1. Rata-rata kadar timbal dalam darah anak di Kabupaten Tangerang adalah 39,18 $\mu \mathrm{g} / \mathrm{dl}$ dimana $100 \%$ melebihi batas normal (CDC 1997) sedangkan ratarata kadar timbal dalam darah anak di Kabupaten Lamongan adalah 11,76 $\mu \mathrm{g}$ / dl dimana 59,4\% melebihi batas normal.

2. Rata-rata prestasi belajar pada ketiga mata pelajaran di Kabupaten Tangerang lebih rendah dibandingkan Kabupaten Lamongan.

3. Ada hubungan yang signifikan dimana siswa yang memiliki kadar timbal darah tinggi mempunyai peluang 3,4 kali untuk .

4. Ada perbedaan proporsi kadar timbal dalam darah dan tingkat kecerdasan (majemuk) antara wilayah Kabupaten Tangerang dan Kabupaten Lamong

5. Variabel yang mempengaruhi hubungan timbal dalam darah terhadap tingkat kecerdasan (majemuk) adalah pendidikan orang tua.

\section{SARAN}

1. Penghilangan sumber pajanan timbal dengan cara menghentikan kegiatan peleburan aki bekas atau memindahkan tempat tinggal dan sekolah anak-anak.

2. Sosialisasi untuk meningkatkan konsumsi makanan yang kaya kalsium, zink dan zat besi pada anak-anak untuk mencegah peningkatan penyerapan timbal dan menurunkan kadar timbal dalam tubuh seperti susu dan produk susu, ikan, udang kecil, teri, rebon, tahu dan taoge [13].

3. Pemeriksaan medis oada anak berkadar timbal darah tinggi untuk mengetahui ada tidaknya gangguan kesehatan dan melakukan terapi kelasi pada anak-anak dengan kadar timbal darah $45 \mu \mathrm{g} / \mathrm{dl}-69$ $\mu \mathrm{g} / \mathrm{dl}$.

4. Pencegahan dan deteksi dini pencemaran timbal dilakukan dengan pemantauan kadar timbal di udara secara rutin dan skrining timbal dalam darah pada masyarakat di sekitar peleburan aki bekas.

5. Penyampaian hasil-hasil penelitian tentang dampak timbal terhadap kecerdasan kepada orang tua, guru, masyarakat dan pemerintah setempat dengan harapan pemerintah dan masyarakat meningkatkan mutu layanan pendidikan sedangkan orang tua dan guru memberikan perhatian khusus serta motivasi kepada anak-anak dengan gangguan kecerdasan.

6. Perlu diadakan penelitian lebih lanjut terkait dampak kesehatan timbal lainnya misalnya gangguan pertumbuhan badan anak-anak dan analisis spasial dispersi 
timbal di udara. Penggunaan nilai Ujian Nasional patut dipertimbangkan sebagai pengganti nilai rapor dikarenakan berstandar dan digunakan secara nasional.

\section{UCAPAN TERIMA KASIH}

Ucapan terima kasih disampaikan kepada Dr. Esrom Hamonangan, Dr. Budi Haryanto, Bapak Bambang Hindratmo, Dr. Ririn Arminsih, Ibu Sri Tjahyani, Dr. PA. Kodrat Pramudho, LSM KPBB, SD N Bulutengger dan MI Baitussaa'adah.

\section{DAFTAR PUSTAKA}

(1) McGranahan, G., \& Murray, F. (2003). Air Pollution and Health in Rapidly Developing Countries. London: Earthscan Publications Ltd.

(2) WHO. (2015). Lead Poisoning and Health. Tersedia di: www.who.int/ mediacentre/factsheets/fs379/en/ [diakses 11 November 2015]

(3) Frumkin, H. (2010). Environmental Health From Global to Local. USA: Jossey-Bass.

(4) WHO. (2010). Childhood Lead Poisoning. Genewa: WHO.

(5) Wantimpres. (2014). Menuju Pengelolaan Aki Bekas yang Ramah Lingkungan. Tersedia di: http:// www.indonesia.go.id/in/penjelasan-umum/14147-menuju-pengelolaan-aki-bekas-yang-ramah-lingkungan?format= pdf [diakses 1 September 2015]

(6) Pramudiarja, A. U. (2014). Peleburan Aki Bekas: Penebar Racun yang Terabaikan. Tersedia di: m.detik. com/health/read/2014/01/10/135511 /2464003/763/peleburan-aki-bekaspenebar-racun-yang-terabaikan [diakses 10 September 2015]

(7) Wulandari, R. A. (1992). Hubungan antara Beberapa Faktor yang Berpengaruh pada Pemaparan Timah Hitam (Pb) dalam Darah Pekerja Peleburan Aki Bekas di Jakarta Barat dan Kecamatan Ciampea Bogor 1992. [Tesis] Depok: FKM UI

(8) Needleman, H. L. (2000). The Removal of Lead from Gasoline: Historical and Personal Reflections. Environmental Research, 20 - 35.

(9) WHO. (2002). The World Health Report 2002: Reducing Risks, Promoting Healthy Life. Geneva: WHO

(10) WHO. (1977). Environmental Health Criteria 3 : Lead. Tersedia di: http://www.inchem.org [diakses 1 September 2015]

(11) Lanphear, dkk. (2005). Low-Level Environmental Lead Exposure and Children's Intellectual Function: an International Pooled Analysis. Environ. Health Perspect, 894-899.

(12) ATSDR. (2007). Toxicological Profile for Lead. Atlanta: US. Department of Health and Human Services.

(13) Haryanto, B. (2008). Pengaruh Suplemen Kalsium terhadap Penurunan Kadar Timah Hitam dalam Darah. [Disertasi]. Depok: FKM UI 